\title{
Pemodelan Hubungan Hujan, Limpasan dan Kapasitas Erosi pada Suatu DAS yang Masuk ke Palung Sungai
}

\author{
Hang Tuah Salim ${ }^{1, *)}$, M. Syahril Badri Kusuma ${ }^{1, *)} \&$ Nazili $^{2, \dagger)}$ \\ ${ }^{1)}$ Fakultas Teknik Sipil dan Lingkungan, Institut Teknologi Bandung \\ ${ }^{2)}$ Kelompok Riset Eko-Hidraulik-Pusat Rekayasa Industri, Institut Teknologi Bandung
}

\begin{abstract}
Abstrak. Makalah ini menyajikan kajian model matematik mengenai hubungan antara pola hujan, aliran permukaan dan erodibilitas pada DAS (Daerah Aliran Sungai) dengan tingkat sedimentasi di sungai. Parameter studi tersebut dikaitkan dengan beberapa faktor yang mempengaruhinya, seperti tata guna lahan, jenis tanah, topografi, kemiringan lahan, curah hujan, dan lain-lain. Untuk mengkaji karakteristik pengaliran di DAS dan sungai tersebut telah digunakan model matematik ANSWERS. Penerapan model ini memberikan prediksi mengenai besar pola dan debit aliran permukaan pada tiap inlet pada ruas sungai yang terjadi akibat adanya hujan. Hasil studi yang telah dilakukan pada DAS Cipeles menunjukkan bahwa variabel yang amat berpengaruh adalah tata guna lahan dan pola hujan yang akan mempengaruhi parameter lainnya seperti erosi lahan dan karakteristik pengaliran. Hasil pemodelan telah menunjukan adanya keserupaan pada kecenderungan/pola aliran dan sedimentasi yang cukup baik dengan hasil observasi. Namun demikian terdapat perbedaan yang cukup signifikan dari sisi kuantitas debit dan sedimentasi. Ketidakakurasian ini dapat diperbaiki dengan pengembangan model lebih lanjut dan penggunaan data kalibrasi yang lebih baik, terutama data hujan dan debit yang dapat mewakili kondisi tata guna lahan dari DAS yang bersangkutan.
\end{abstract}

\begin{abstract}
This paper present the results of the mathematical model study on the relation between rain fall pattern, surface run off flows and land erodibility of a catchment area and river sedimentation. The influences of catchment area characteristics such as land use, soil behavior, topography condition and other related physical condition is encountered. Surface flow assessment is done at each sub catchment area by using mathematical model named ANSWER. Case study on Cipeles Catchmen area had shown that land use and rain fall pattern are the main parameter. Good agreement between model result and observation is shown on surface run off flow and sediment pattern, but there is still significant inaccuracy in its magnitude. This inaccuracy could be minimized not only by improving the model but also using a better data calibration, such as highly correlated rain fall and river discharge data with catchment area land use condition.
\end{abstract}

Keywords: Mathematical model; Surface run off flow; erodibilty; river sedimentation.

\footnotetext{
* Staf pengajar Program Studi Teknik Sipil ITB.

${ }^{\dagger}$ Peneliti pada Kel. Riset Eko-Hidrulik PRI ITB dan Asisten KBK TSA Program Studi Teknik Sipil ITB.
} 


\section{$1 \quad$ Pendahuluan}

Keberadaan dan kondisi eksosistem Daerah Aliran Sungai (DAS) atau sering disebut cekungan sungai merupakan salah satu isu nasional dalam beberapa tahun terakhir. Hal ini dikarenakan salah satu variabel terjadinya banjir adalah kondisi DAS yang kritis, seperti terjadinya penyimpangan tata guna lahan. Kondisi ini menyebabkan berkurang atau malah hilangnya daerah resapan sebagai penyangga terhadap beban banjir yang terlalu besar akibat tingginya curah hujan yang terjadi.

Pada sisi lain, kondisi sungai juga sangat mempengaruhi terhadap kapasitas angkut akibat limpasan langsung (run off) dari DAS. Kondisi ini dapat dikatakan bahwa manajemen DAS (dalam artian lahan, penutup, dan lain-lain), karakteristik sungai sangai mempengaruhi terhadap bencana banjir yang sering terjadi dalam beberapa tahun terakhir. Di luar variabel tersebut, partisipasi masyarakat dalam ikut peduli terhadap kesinambungan lingkungan sangat signifikan mengurangi beban banjir yang terjadi.

Menurut Sinukaban (1995), pemanfaatan sumberdaya alam DAS yang tidak memperhatikan kemampuan dan kelestarian lingkungan, akan terjadi kerusakan ekosistem dan tata guna air. Oleh karena itu dalam membuat perencanaan pengelolaan DAS, pilihan teknologi yang tepat adalah berlandaskan kaidahkaidah konservasi. Karakteristik DAS yang pengaruhnya dominan, meliputi struktur batuan dan geologi, morfometri DAS (bentuk dan luas) DAS), tanah, vegetasi dan tats lahan, (Sosrodarsono dan Takeda, 1987).

Oleh sebab itu untuk memperhitungkan besarnya hujan yang akan memasuki palung sungai sangat tergantung pada kondisi DAS dengan beberapa variabel yang berpengaruh seperti tata guna lahan, jenis penutup, jenis tanah maupun pola curah hujan yang terjadi pada wilayah tersebut. Disamping itu hujan yang menjadi limpasan pada permukaan DAS secara otomatis akan mengerosi lapisan atas lahan, yang selanjutnya akan dibawa ke palung sungai. Oleh sebab itu untuk memprediksi volume sedimen yang dibawa oleh sungai sangat tergantung kondisi DAS dan pola hujan yang terjadi, disamping karakteristik sungai itu sendiri.

Berdasarkan hal tersebut di atas, dalam paper ini dilakukan pengkajian tentang hubungan limpasan akibat fenomena curah hujan yang menyebabkan terjadinya erosi lahan. Sebagian dari erosi lahan ini akan masuk ke palung sungai. Dalam paper ini dibatasi hanya mengkaji pola hubungan hujan, limpasan dan erosi lahan yang terjadi berdasarkan variasi curah hujan. Ada tiga pola curah hujan yang ditinjau dalam tulisan ini, sehingga kesimpulan yang diberikan berdasarkan variasi pola curah hujan tersebut. 


\section{Pergerakan Sedimen di DAS}

\subsection{Proses Erosi Tanah oleh Air}

Erosi tanah oleh air adalah pemindahan tanah dari tempat asalnya oleh aliran air di lahan. Tipe erosi tanah oleh air adalah:

- Terpisahnya antara butiran-butiran tanah karena kejatuhan air (raindrops impact)

- Terbawa hanyutnya butiran di lahan oleh aliran air di lahan (overland flow)

Erosi tanah oleh air dipengaruhi oleh berbagai faktor, seperti kondisi hidrologi, tanah, tata guna lahan, dan topografi.

\subsection{Laju Sedimen di Daerah Pengaliran Sungai (DPS)}

Dalam kaitannya dengan erosi di DPS, sedimen adalah hasil akhir dari proses erosi lempeng (sheet erosion) permukaan tanah dan erosi alur (gully erosion) yang diangkut oleh air. Erosi lempeng ditambah erosi alur disebut sebagai erosi gros (gross erosion).

Bagian dari hasil erosi yang terangkut sampai di tempat pengukuran di hilir disebut hasil sedimen (sediment yield). Laju sedimen rata-rata (sediment yield) adalah laju sedimen per satuan luas DPS.

Wischmeier dan Smith (1965) secara empiris menyimpulkan bahwa besarnya erosi pada titik kontrol sebuah DAS sebanding dengan erosi gross dikalikan dengan ratio pelepasan sedimen (sediment delivery ratio). Pada dasarnya metoda ini hanya cocok untuk DAS dengan luas kurang dari $10 \mathrm{~km}^{2}$. Untuk DAS dengan luas lebih besar perlu dilakukan pengukuran sedimen (sampling). Beberapa faktor yang perlu diperhatikan pada metoda ini antara lain : erosivitas hujan, erodibilitas tanah, panjang dan kemiringan lereng, konservasi tanah dan pengelolaan tanaman, laju erosi potencial, laju erosi aktual dan laju sedimentasi potencial. Metoda yang lebih dikenal sebagai formula USLE (Universal Soil Losses Equation) ini telah diteliti lebih lanjut oleh Balai Penelitian Tanah Bogor untuk disesuaikan pemakaiannya terhadap jenis tanah dan kondisi di Indonesia.

\subsection{Tataguna Lahan}

Evaluasi lahan, merupakan salah satu komponen penting dalam proses perencanaan penggunaan lahan (land use planning) yang hasilnya dapat memberikan alternatif penggunaan lahan dan batas-batas kemungkinan penggunaannya, serta tindakan penegelolaan yang diperlukan agar lahan dapat berfungsi secara lestari, (FAO, 1976 dalam Arsyad, 1989). 


\section{Model Hubungan Hujan, Limpasan, dan Kapasitas Erosi}

\subsection{Beberapa Model Hidrologi Untuk Daerah Aliran Sungai}

Sebagai analisis untuk DAS, kategori utama dapat dibedakan menjadi model dengan lumped parameter berlawanan dengan parameter terdistribusi, model kejadian sesaat (event) berlawanan dengan model berkesinambungan (continous) dan stochastic versus deterministic, model empirik dan mekanistik, model deskriptif versus model numerik, model dinamik versus model statik. beberapa model hidrologi dengan sistem lumped parameter antara lain : Mock's model, Dowdy-O'Donell, NAM Model, TANK model, Simple Deterministic Model, Stanfford Model, Hanya sedikit sekali tersedia model skala dengan parameter yang terdistribusi untuk pemodelan NPS (non point source) dari suatu DAS, disini termasuk ANSWERS (Huggins and Monke 1966; Dillaha dan Beasley 1983), FESHM (Ross et al,1982), AGNPS (Young et al,1987), dan SHE (Abott et al, 1986). Model distribusi secara teoritis mengasumsikan bahwa DAS dibangun menjadi terstruktur oleh elemen-elemen homogen yang tidak begitu luas setara dengan titik-titik didalam DAS.

Untuk melihat pola hubungan antara curah hujan, limpasan (run off) dan kapasitas erosi pada suatu Daerah Aliran Sungai dapat dilakukan pemodelan baik dengan model matematik maupun model fisik. Dalam penelitian ini pemodelan dilakukan dengan menggunakan model matematik, dalam hal ini digunakan model ANSWERS (Areal Nonpoint Source Watershed Environment Response Simulation). Model ANSWERS ini dikembangkan pertama kali oleh (Beasley,huggins dan Dillaha 1983), dan yang sudah diintegrasikan dengan GIS (A.P.J. de Roo et al 1989), dan versi sekarang ini ANSWERS-2000 (Bourouai dan Dilllaha 1998) merupakan model simulasi yang kontinyu dikembangkan untuk mensimulasikan runoff dan erosi rata-rata tahunan jangka panjang (long term average annual) dari suatu DAS.

ANSWERS adalah salah satu model yang dapat digunakan untuk mensimulasikan karakteristik DPS pada saat dan setelah terjadinya hujan. Prinsip dasar model ANSWERS adalah bahwa pada setiap titik di dalam DPS, terdapat hubungan fungsional antara debit aliran air dan parameter-parameter hidrologi seperti intensitas hujan, infiltrasi, kondisi topografi, dan jenis tanah.

Parameter-parameter seperti kondisi topografi, jenis tanah, tata guna lahan, intensitas hujan, digunakan oleh model untuk menggambarkan karakteristik DPS. Dari pemodelan ini dapat diketahui berapa besar debit aliran permukaan yang terjadi akibat adanya hujan.

Sebagaimana disebutkan di atas bahwa salah satu faktor utama penyebab erosi tanah oleh air adanya aliran permukaan. Debit aliran permukaan yang 
didapatkan dari model ANSWERS ini pada tahap selanjutnya digunakan sebagai basis bagi pemodelan erosi lahan yang terjadi di DPS.

Hubungan parameter-paramater yang digunakan dalam pemodelan diuraikan secara singkat sbb:

1. Karakteristik aliran

Secara matematis, setiap elemen tanggapan hidraulis (hydraulic response) dapat dihitung sebagai suatu fungsi waktu sbb:

$$
\mathrm{I}-\mathrm{Q}=\mathrm{ds} / \mathrm{dt}
$$

dimana :

I = debit inflow menuju suatu elemen dari hujan dan dari elemen sekitarnya

$\mathrm{Q}=$ debit outflow

$\mathrm{S}=$ volume air yang disimpan (stored) dalam suatu elemen

$\mathrm{t}=$ waktu

DPS dibagi menjadi elemen-elemen, dimana masing-masing elemen merepresentasikan bidang aliran permukaan, dengan arah aliran menuju ke titik yang memiliki perbedaan elevasi tertinggi.

Detensi air permukaan (surface detention) adalah volume air yang harus terkumpul sebelum aliran permukaan dapat terjadi. Detensi air dapat dihitung sebagai total volume air permukaan dalam suatu elemen dikurangi dengan volume retensi. Dengan demikian kapasitas volume retensi harus terpenuhi dahulu sebelum air masuk ke dalam tampungan detensi dan aliran permukaan. Detensi air permukaan adalah komponen yang memiliki pengaruh kuat terhadap aliran permukaan dan karakteristik drainase DPS. Permukaan tanah yang kasar (rough) dapat menyimpan air dalam jumlah yang lebih besar dibandingkan dengan permukaan yang halus. Persamaan yang digunakan dalam model ANSWERS adalah:

$$
\mathrm{DEP}=\mathrm{HU} * \mathrm{ROUGH} *(\mathrm{H} / \mathrm{HU})^{1 / \text { ROUGH }}
$$

dimana:

DEP $=$ volume tampungan air (dalam satuan kedalaman)

$\mathrm{H}=$ ketinggian di atas datum

$\mathrm{HU}=$ ketinggian maksimum micro-relief

ROUGH $=$ parameter karakteristik permukaan

2. Curah Hujan, Intersepsi, dan Evaporasi

Dalam pemodelan ini, intersepsi diasumsikan seragam untuk masingmasing jenis tumbuhan. Menurut Horton (1919) besar intersepsi oleh 
tumbuhan adalah sekitar $0,5 \mathrm{~mm}$ hingga $1,8 \mathrm{~mm}$. Dalam perhitungan selanjutnya, besarnya evaporasi selama terjadinya hujan diabaikan.

3. Infiltrasi

Persamaan infiltrasi yang digunakan dalam pemodelan ANSWERS adalah persamaan Holtan (1961) dan Overton (1965).

$$
\mathrm{FMAX}=\mathrm{FC}+\mathrm{A} *(\mathrm{PIV} / \mathrm{TP})^{\mathrm{P}}
$$

dimana :

FMAX $=$ kapasitas infiltrasi dengan permukaan tanah terendam air

$\mathrm{FC}=$ kapasitas infiltrasi akhir pada saat mencapai harga konstan

A $\quad=$ kapasitas infiltrasi maksimum setelah FC tercapai

$\mathrm{TP}=$ total volume ruang pori

PIV $\quad=$ volume air yang dapat disimpan sebelum jenuh

$\mathrm{P}=$ koefisien non dimensional, merepresentasikan korelasi antara antara tingkat penurunan infiltrasi dengan peningkatan kelembaban tanah

Pergerakan air di zona ini mengikuti prinsip sebagai berikut:

- Jika kadar air dalam zona kontrol lebih kecil daripada kapasitas lapangan (field capacity), maka tidak ada pergerakan air dalam zona ini

- Jika kadar air dalam zona kontrol lebih besar daripada kapasitas lapangan (field capacity), maka air bergerak mengikuti persamaan sbb:

$\mathrm{DR}=\mathrm{FC} *(1-\mathrm{PIV} / \mathrm{GWC})^{3}$

dimana

DR = laju pergerakan air dai zona kontrol

GWC = kapasitas air gravitasional pada zona kontrol (= porositas dikurang dengan kapasitas lapangan)

4. Sedimen

Dalam model ANSWER, terpisahnya butiran tanah akibat tumbukan air hujan dapat dihitung menggunakan persamaan Meyer dan Wishmeier (1969).

$$
\mathrm{DETR}=0,108 * \mathrm{CDR} * \mathrm{SKDR} * \mathrm{~A}_{\mathrm{i}} * \mathrm{R}^{2}
$$

dimana

DETR = laju pemisahan butiran tanah akibat tumbukan air hujan $(\mathrm{kg} / \mathrm{min})$

$\mathrm{CDR}=$ faktor cara penanaman dan manajemen lahan $(\mathrm{C})$ berdasarkan USLE dan Wishmeier \& Smitth (1978)

SKDR = faktor erosivitas lahan $(\mathrm{K})$ berdasarkan USLE

$\mathrm{A}_{\mathrm{i}} \quad=$ pertambahan luas $\left(\mathrm{m}^{2}\right)$

$\mathrm{R}=$ intensitas hujan $(\mathrm{mm} / \mathrm{min})$ 
Sementara itu, pemisahan butiran tanah akibat aliran permukaan dihitung berdasarkan persamaan Meyer dan Wischmeier (1969) yang dimodifikasi oleh Foster (1976) sebagai berikut:

$$
\mathrm{DETF}=0,9 * \mathrm{CDR} * \mathrm{SKDR} * \mathrm{~A}_{\mathrm{i}} * \mathrm{SL} * \mathrm{Q}
$$

dimana

DETF = laju pemisahan butiran tanah akibat overland flow $(\mathrm{kg} / \mathrm{min})$

$\mathrm{SL} \quad=$ kemiringan lereng

$\mathrm{Q}=$ debit per satuan lebar $\left(\mathrm{m}^{2} / \mathrm{min}\right)$

Kapasitas transport sedimen yang digunakan dalam model ANSWERS mengikuti hasil penelitian Yalin (1963), Meyer dan Wischmeier (1969), Foster dan Meyer (1972), dan Curtis (1976). Persamaan yang dapat digunakan adalah sbb:

$$
\begin{aligned}
& \mathrm{TL}=161 * \mathrm{SL} * \mathrm{Q}^{5} \\
& \left(\text { jika } \mathrm{Q} \leq 0.046 \mathrm{~m}^{2} / \mathrm{min}\right) \\
& \mathrm{TL}=16320 * \mathrm{SL} * \mathrm{Q}^{5} \\
& \left(\text { jika } \mathrm{Q} \geq 0.046 \mathrm{~m}^{2} / \mathrm{min}\right)
\end{aligned}
$$

dimana

$\mathrm{TF}=$ laju transport sedimen potensial $(\mathrm{kg} / \mathrm{min} . \mathrm{m})$

Perhitungan erosi dalam ANSWERS dilakukan dengan beberapa penyederhanaan dan asumsi sebagai berikut:

- Aliran air berupa subsurface water tidak memproduksi sedimen

- Butiran sedimen yang bergerak dari suatu titik dan mengendap pada titik laina akan menumpuk pada permukaan tanah

- Pemisahan kembali (re-detachment) butiran tanah memerlukan energi yang sama dengan pemisahan butiran tanah semula (original detachment)

- Pada ruas saluran, tidak terjadi pemisahan butiran tanah akibat tumbukan air hujan, dan hanya sedimen yang telah mengendap di saluran saja yang diperhitungkan terhadap efek pemisahan butiran akibat aliran air (dasar saluran tidak tererosi)

\section{$4 \quad$ Penggunaan Model Answers}

ANSWERS ini merepresentasikan suatu DAS sebagai kumpulan elemen bujur sangkar (square cells) seperti terlihat dalam gambar dibawah ini, dimana didalamnya parameter-parameter (jenis tanah, kondisi permukaan, vegetasi, topografi dll) yang signifikan dalam seluruh proses hidrologi diasumsikan homogen. 
Model ANSWERS adalah model deterministik yang berdasarkan pada hipotesis setiap titik didalam DAS, mempunyai hubungan fungsi antara air dan parameter hidrologinya, antara lain intensitas hujan, infiltrasi, topografi, dan jenis tanah.

Model distribusi DAS, dipengaruhi oleh variabel ruang (spasial), parameterparameter pengendali seperti topografi, tanah, tataguna lahan, alur sungai dan parameter hidrologinya yang selanjutnya dilakukan dalam suatu algoritma komputasi.

Ada beberapa pertimbangan, mengapa digunakan model ANSWERS, antara lain keuntungan dari model ini adalah sebagai berikut

- Dapat memberikan keluaran sekaligus, baik berupa debit aliran pada sungai, kehilangan tanah akibat erosi, dan sedimentasi.

- Mampu memproses kerja simulasi (skenario) secara serentak dalam berbagai kondisi DAS.

- Menganalisis parameter terdistribusi secara sensitif sehingga dapat menghasilkan simulasi akurat terhadap sifat fisik DAS.

Sedangkan kelemahan dari model ini antara lain

- Untuk DAS berukuran besar (lebih dari $100 \mathrm{~km}^{2}$ ) hasilnya kurang akurat dan cukup baik untuk DAS ukuran sedang (kurang dari $10.000 \mathrm{ha}$ )

- Bukan merupakan model time series (bukan kontinu), sehingga pendekatan keluarannya hanya sekali atau pada kurun waktu tertentu dan tidak selamanya.

Dalam model ANSWERS suatu kejadian hujan dapat disimulasikan dalam satu detik hingga beberapa menit, mempergunakan data dari satu hingga tiga pengukur hujan, dengan parameter terdistribusi pada setiap bujursangkar, sehingga pengaruh variabel yang terdistribusi dalam DAS dapat diperhitungkan secara matematis. Hujan yang jatuh sebagian terintersepsi pada tajuk tanaman (PER), hingga mencapai kapasitas intersepsi potensial (PIT). Apabila hujan yang terjadi melebihi kapasitas intersepsi potensial, proses infiltrasi akan mulai terjadi, infiltrasi dipengaruhi oleh kondisi lengas tanah awal (ASM), porositas total (TP), kapasitas lapang tanah (FP), laju infiltrasi konstan (FC), selisih laju infiltrasi maksimum dengan laju infiltrasi konstan (A), dan kedalaman zone pengamatan infiltrasi (DF). Laju infiltrasi akan berkurang secara exponensial, dan akan mencapai konstan. Pada saat yang bersamaan dengan hujan yang jatuh, apabila melebihi infiltrasi dan intersepsi, maka air akan tertahan di lekukan kecil (micro depression) di permukaan tanah disebut relenlion storage, didefinisikan dengan variabel RC dan HU. Saat tampungan permukaan melebihi kapasitas micro depression, maka terjadilah limpasan permukaan. 


\subsection{Keluaran Model ANSWERS}

Keluaran model ANSWERS berupa

1. Menyajikan karakteristik DAS yang meliputi luas elemen, luas DAS, lokasi outlet, jumlah percabangan channel, slope DAS (minimum, rata-rata dan maximum), slope channel (minimum, rata-rata dan maximum), luas areal yang diolah, lengas tanah, kapasitas lapang, koefisien drainase, fraksi aliran bawah permukaan, erosi rata-rata, erosi maksimum, pengendapan maksimum.

2. Tampilan limpasan permukaan, intensitas hujan dan sedimen terlarut.

Tampilan 2D arah limpasan setiap elemen, erosi setiap elemen, dan channel.

\section{$5 \quad$ Verifikasi dan Simulasi Model}

\subsection{Sub Daerah Aliran Sungai Cipeles}

Domain model yang digunakan dalam verifikasi dan simulasi ini adalah Sub Daerah Aliran Sungai (Sub DAS) Cipeles Kabupaten Sumedang Propinsi Jawa Barat. Lihat gambar di bawah. Sub DAS Cipeles merupakan bagian dari DAS Cimanuk (Cimanuk Tengah) yang meliputi 8 kecamatan dengan 108 desa. Menurut BRLKT Cimanuk-Citanduy (2000) dalam Taufik, I (2003) luas Sub DAS Cipeles sekitar $303 \mathrm{~km}^{2}$.

Secara geografis Sub DAS Cipeles membentang dari 107045'34'"- 10801'57' Bujur Timur dan 06 45 '57'- 06 $57^{\circ} 59^{\prime}$ 'Lintang Selatan. Menurut BRLKT Cimanuk-Citanduy (2000) dalam Taufik, I (2003) sebagian besar topografi Sub DAS Cipeles dibentuk oleh gunung-gunung, yaitu sekitar $67.67 \%$, sedangkan sisanya bertopografi datar sampai berbukit-bukit.

Data dari sumber yang sama, iklim pada daerah ini didominasi oleh iklim tropis yang dipengaruhi oleh angin muson, yang menurut Schmidt dan Ferguson (1951) iklim Sub DAS termasuk tipe iklim D, dengan curah hujan tahunan berkisar antara 645-2379 $\mathrm{mm}$.

Pada sub DAS ini sungai utamanya adalah sungai Cipeles dengan panjang sekitar $61 \mathrm{~km}$ yang sepanjang tahun tidak pernah kering. Anak sungai yang mengalir ke sungai Cipeles ada 11 anak sungai, yaitu sungai Ciherang, Ciseda, Cipongkor, Cisugan, Cipicung, Cileuleuy, Cihonje, Cikoneng, Ciderma, Cicapar dan sungai Ciraden.

Berdasarkan data dari Bakosurtanal (1997) dalam Taufik, I (2003), pada Sub DAS Cipeles terdapat 6 pola penggunaan lahan, yaitu sawah, pemukiman/kampung, kebun, tegalan/tanah kosong, dan hutan. 
Untuk mendapatkan informasi tentang seberapa jauh pengaruh hujan dan perubahan lahan yang menyebabkan erosi lahan, yang akhirnya menyebabkan turunnya kualitas Sub DAS Cipeles itu sendiri, maka dilakukan verifikasi dan simulasi model dengan menggunakan model ANSWERS. Data inputnya berupa hujan, tata guna lahan, topografi (termasuk kemiringan lahan) serta beberapa parameter lainnya. Posisi dari pos hujan yang ada pada Sub DAS Cipeles dan sekitarnya dapat dilihat pada gambar 1 di bawah ini.

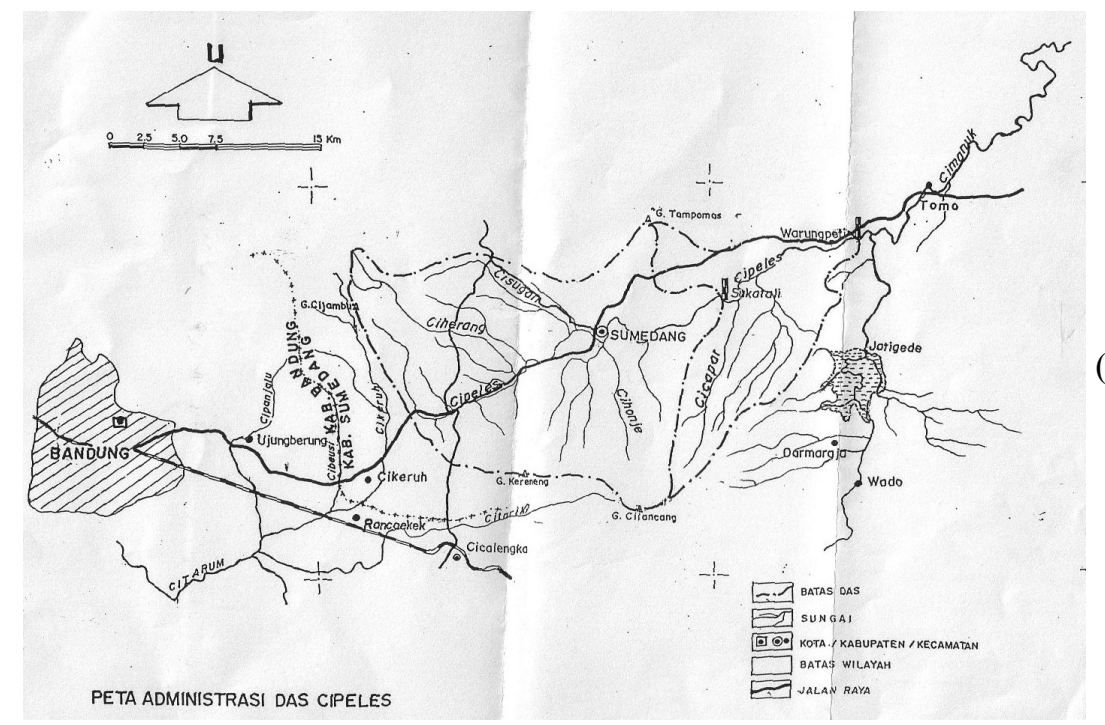

(a)

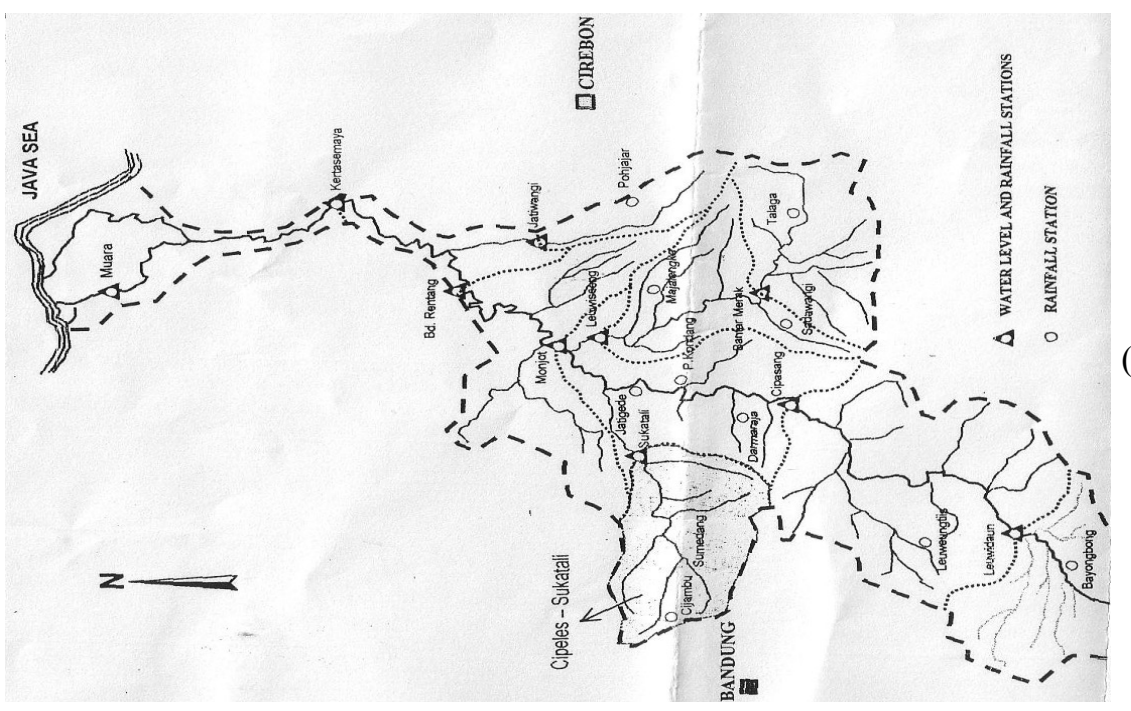

(b)

Gambar 1 (a) Peta Administrasi Sub DAS Cipeles, (b) Posisi pos/stasiun pengukuran muka air dan curah hujan pada Sub DAS Cipeles dan sekitarnya. 
Pos hujan yang digunakan dalam kasus ini adalah pos hujan Sukatali (R1) di bagian hilir sungai Cipeles dan pos hujan Cijambu (R2) pada bagian hulu Sungai Cipeles.

Berdasarkan peta DAS Cipeles di atas, selanjutnya dilakukan generalisir dengan membuat domain model dalam bentuk elemen-elemen seperti gambar 2 berikut. Ukuran dari domain ini adalah $1000 \times 1000 \mathrm{~m}^{2}$.

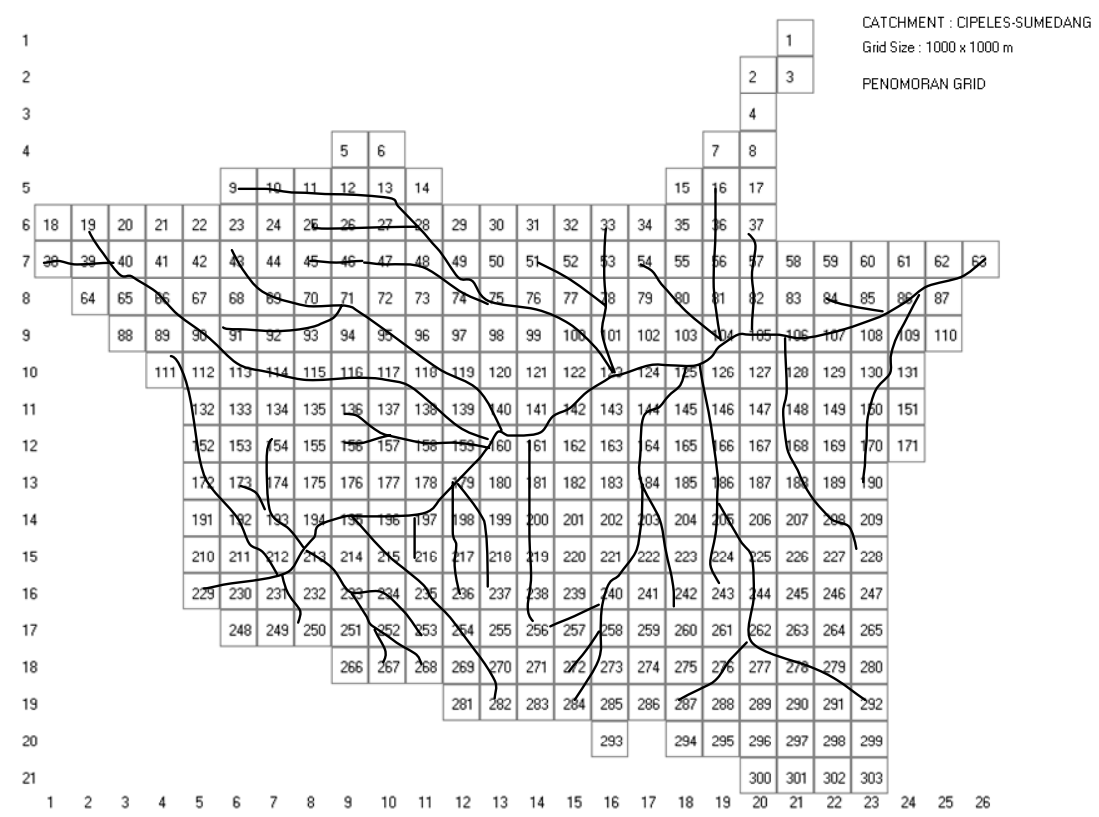

Gambar 2 Definisi domain model ANSWERS untuk Sub DAS Cipeles.

Sedangkan data spasial lainnya sepeti tata guna lahan, elevasi, kemiringan, arah aliran dan jenis tanah dapat dilihat pada gambar $3 \mathrm{~s} / \mathrm{d}$ gambar 7 di bawah ini.

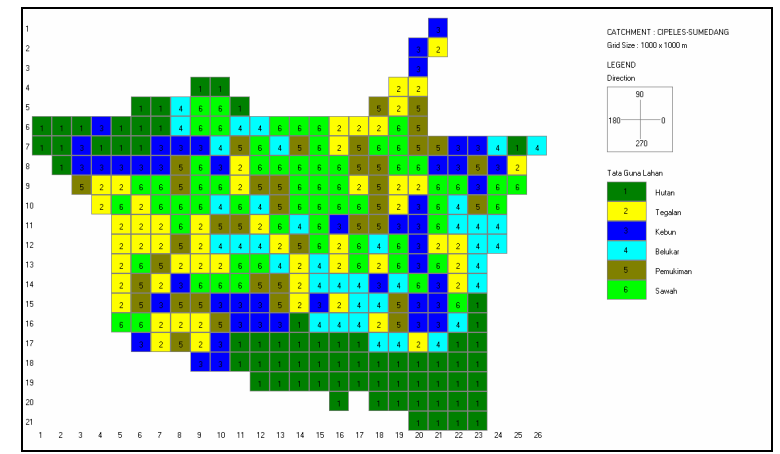

Gambar 3 Pola tata guna lahan pada Sub DAS Cipeles. 


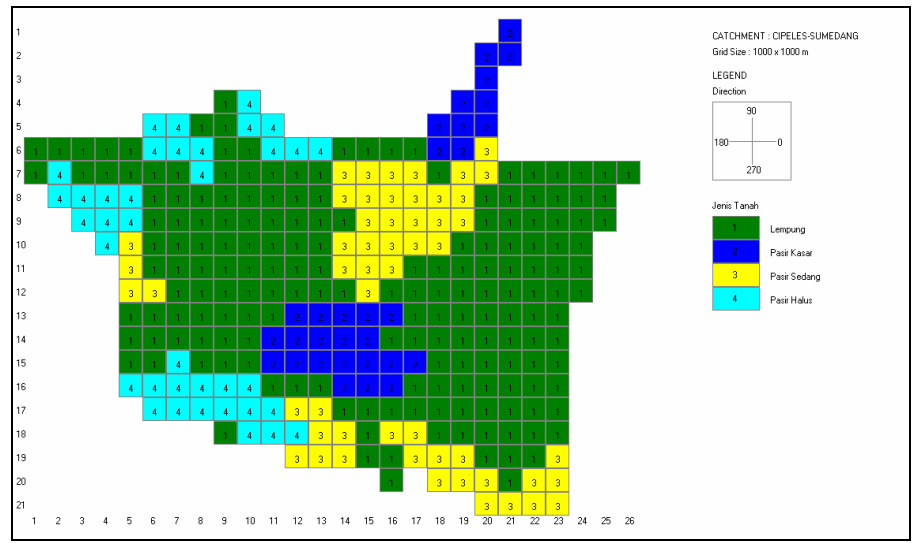

Gambar 4 Jenis tanah pembentuk sub DAS Cipeles.

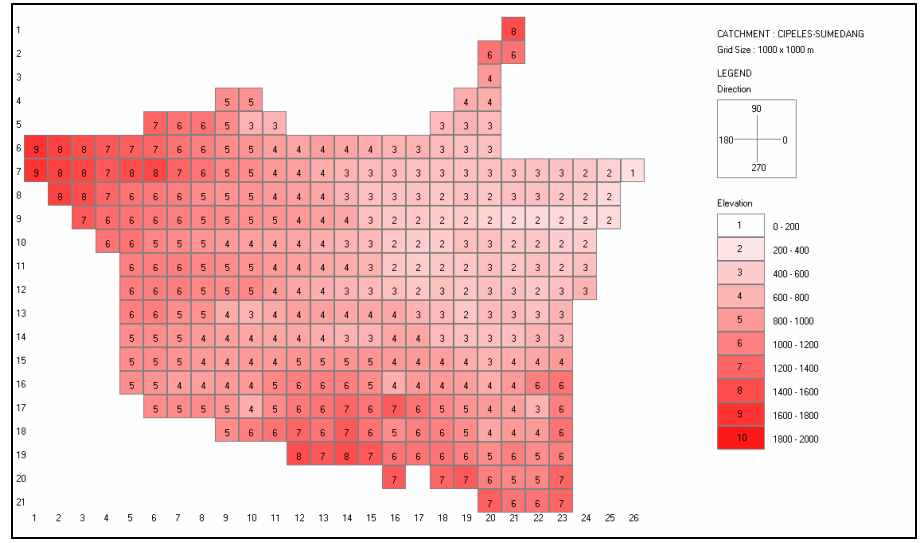

Gambar 5 Kondisi topografi Sub DAS Cipeles.

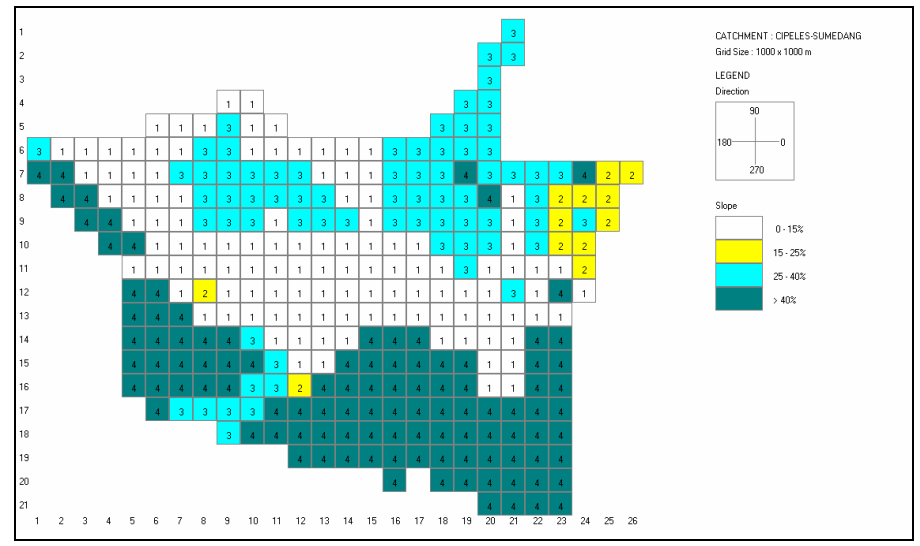

Gambar 6 Kemiringan lahan Sub DAS Cipeles. 


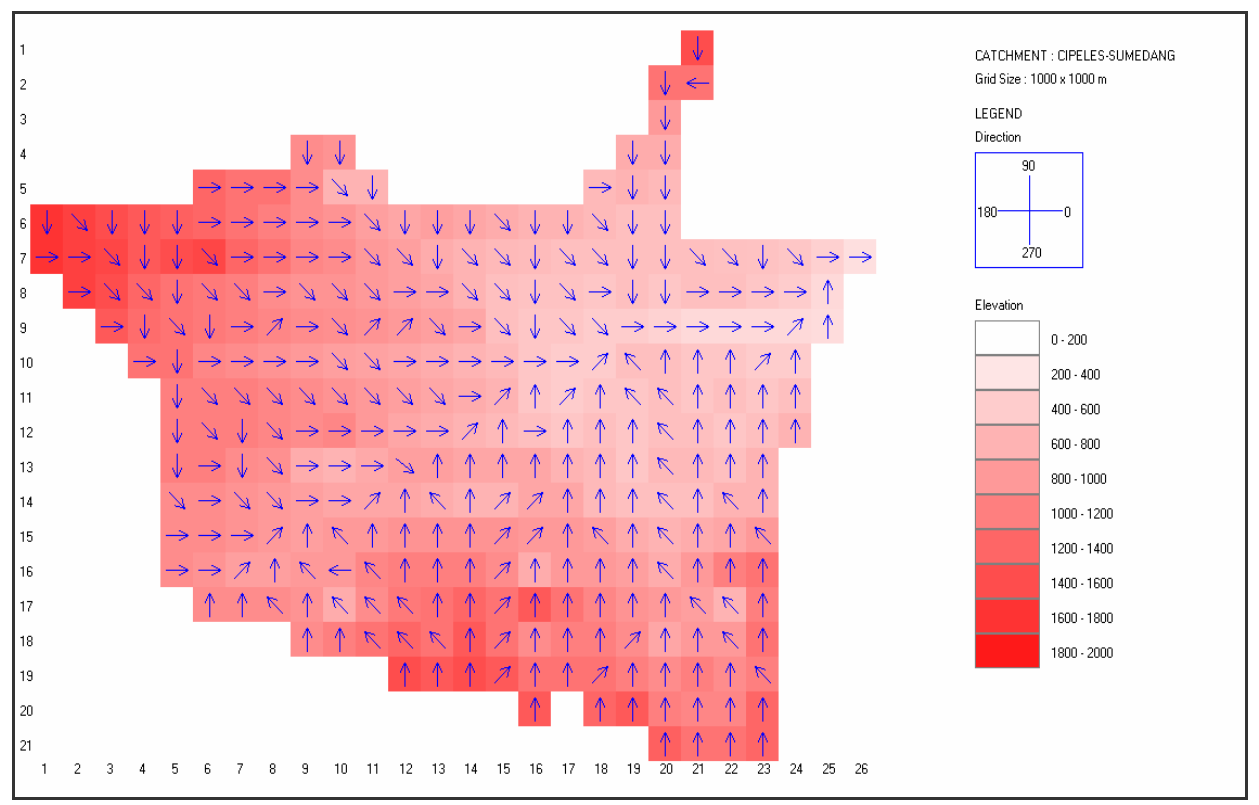

Gambar 7 Arah aliran pada Sub DAS Cipeles.

\subsection{Verifikasi Model}

Proses verifikasi model ANSWERS menggunakan dua jenis data dengan fungsi yang berbeda. Kedua data tersebut adalah data curah hujan dan data debit pada kejadian yang sama pada saat pengukuran dilakukan, yaitu pada tanggal 19 Februari 1994. Data curah hujan digunakan untuk input model ANSWERS, yang salah satu outputnya berupa limpasan (dikonversikan ke debit) dibandingkan dengan data debit hasil pengukuran tersebut di atas. Kondisi tata guna lahan diasumsikan tidak berubah sampai dengan tahun 1997, karena dalam penelitian ini tataguna lahan yang digunakan adalah data tahun 1997.

Hujan yang jatuh pada tanggal 19 Februari 1994 berdasarkan pengamatan 2 pos hujan yaitu: pos Sukatali $=57 \mathrm{~mm}$ dan pos $C$ ijambu $=54 \mathrm{~mm}$ pada sub DAS Cipeles, dapat dimodelkan dengan model ANSWERS dan dianalisis terhadap beberapa parameter inputnya (parameter hidrologi) yang berpengaruh. Output model sekaligus akan menghasilkan hidrograf yang merupakan prediksi aliran permukaan akibat adanya curah hujan yang terjadi pada saat itu seperti terangkum pada Gambar 8.

\subsubsection{Kalibrasi Output Model}

Penggunaan parameter hasil kalibrasi, merupakan parameter yang layak dan dapat digunakan sebagai masukan model pada kejadian hujan yang lain, sehiggga akan mnghasilkan aliran permukaan (run off) atau puncak banjir dan 
rata-rata kehilangan tanah. Kejadian hujan yang dianalisis pada penelitian ini, terjadi pada tanggal 19 Februari 1994. Hujan tanggal 19 februari 1994 setinggi $55.5 \mathrm{~mm}$, selama $7 \mathrm{jam}$, dengan intensitas $7.98 \mathrm{~mm} / \mathrm{jam}$, menyebabkan terjadinya aliran permukaan dengan puncak sebesar $1.6402 \mathrm{~mm} / \mathrm{jam}$ dan puncak banjir di sungai Cipeles $138.050 \mathrm{~m} 3 /$ det, serta terjadi kehilangan tanah rata-rata 5432 $\mathrm{kg} / \mathrm{Ha}$.

Dari hasil pengamatan pencatatan AWR jam jaman pada Pos hujan Sukatali dan Cijambu sebesar $57.00 \mathrm{~mm}, 54.00 \mathrm{~mm}$ dan AWLR pada outlet Sukatali yang tersedia lengkung debitnya, menunjukan bahwa kejadian hujan pada tanggal 19 februari 1994 (aktual) mengakibatkan puncak banjir di Sungai Cipeles sebesar 152,540 m3/det.

\subsubsection{Koefisien Deterministik}

Kalibrasi koefisien determinan dilakukan dengan membandingkan kuadrat rata-rata dari selisih data model dan data lapangan dengan kuadrat rata-rata selisih data lapangan dengan ratarata data lapangan itu sendiri pada kejadian tanggal 19-2-1994, kemudian di hitung berdasarkan persamaan seperti dibawah ini dan hasilnya dapat dibuat tabel.

$$
R^{2}=\frac{\sum\left(Q_{0}-Q_{a v e}\right)^{2}-\sum\left(Q_{0}-Q_{m}\right)}{\sum\left(Q_{0}-Q_{\text {ave }}\right)}
$$

dimana :

Qo $\quad=$ Debit Observasi $\left(\mathrm{m}^{3} / \mathrm{det}\right)$

$\mathrm{Qm}=$ Debit Model $\left(\mathrm{m}^{3} / \mathrm{det}\right)$

$\mathrm{Q}_{\text {ave }}=$ Debit Rata-rata Observasi $\left(\mathrm{m}^{3} / \mathrm{det}\right)$

$\mathrm{R}^{2} \quad=$ Indeks Koefisien Deterministik (Nash \& Sutclife (1970) dalam Deroo (1993))

- $\quad$ Jika modelnya sempuma, maka nilai $(\mathrm{Qo}-\mathrm{Qm})^{2}$ mendekati nol, maka nilai $\mathrm{R}^{2}$ mendekati 1

- Jika $\mathrm{R}^{2}<0$, model menghasilkan simulasi yang jelek clan jauh berbeda dari nilai rata-rata Qavg

Dari perhitungan diperoleh $\mathrm{R}^{2}=0.92$. Berdasarkan koefisien diterministik tersebut, maka verifikasi model ANSWERS dalam kasus ini cukup memuaskan.

\subsubsection{Grafik Puncak Banjir}

Hasil output model pada kejadian tanggal 19 februari 1994 berupa grafik debit (hidrograf), merupakan prediksi yang dibandingkan terhadap hasil pengukuran seperti terlihat pada gambar berikut. 


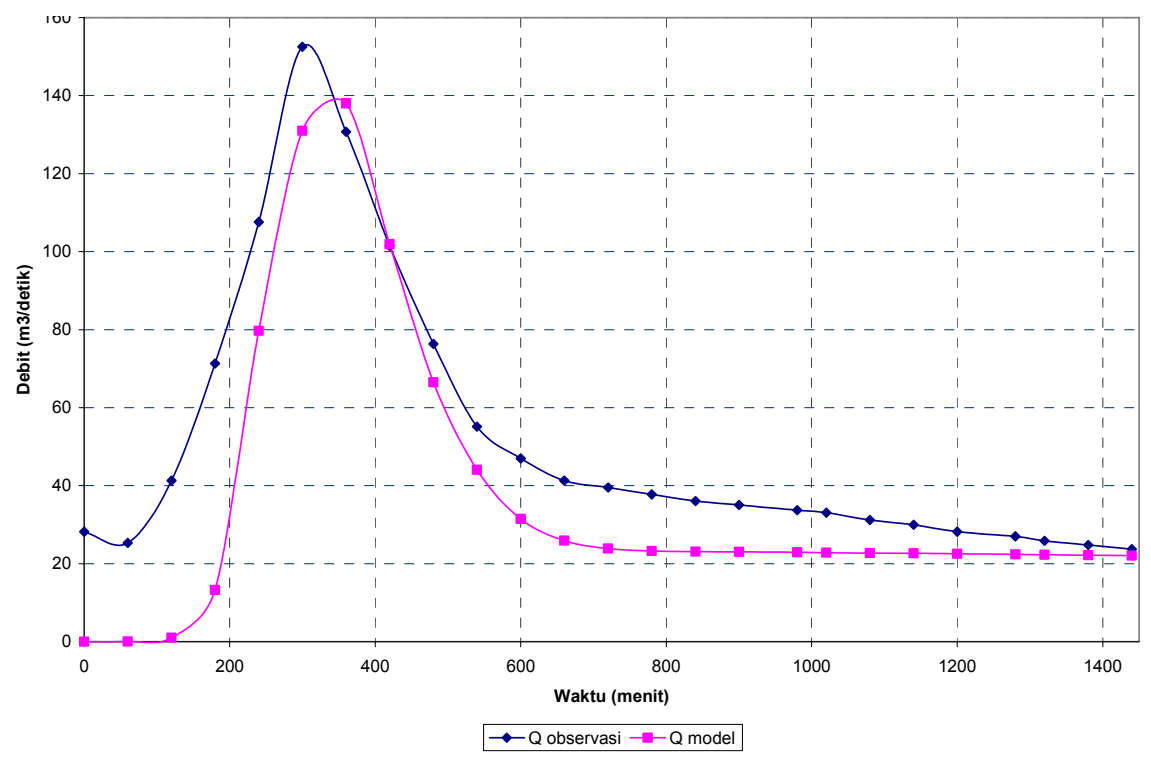

Gambar 8 Hasil perbandingan debit hasil pemodelan dengan pengukuran.

Puncak banjir keluaran model: $1.6402 \mathrm{~mm} / \mathrm{jam}$ X $87.14=142.927 \mathrm{~m}^{3} / \mathrm{det}$ Puncak banjir observasi: $152.54 \mathrm{~m}^{3} / \mathrm{det}$

Hasil kalibrasi puncak banjir: $\frac{(152.540-142.927) \times 100 \%}{152.540}=6.301 \%<10 \%$

Dari hasil kalibrasi puncak banjir tersebut di atas memberikan perkuatan terhadap verifikasi model ANSWERS di atas semakin baik.

\subsection{Simulasi Model}

Setelah dilakukan verifikasi model, selanjutnya dilakukan simulasi model pada Sub DAS Cipeles dalam beberapa skenario, tergantung pola hujan yang terjadi dengan domain model yang sama. Sehingga diperoleh pola hubungan hujan, limpasan dan kapasitas erosi/sedimentasi pada suatu DAS tertentu.

\subsubsection{Skenario 1}

Simulasi ini dilakukan dengan data hujan bersumber pada dua stasiun pengukuran yang berada di sekitar Sub DAS Cipeles. Data ini terukur pada tanggal 19 Februari 1994. Adapun data hujan tersebut seperti tabel berikut ini. 
Tabel 1 Curah hujan pada dua stasiun.

\begin{tabular}{|r|r|r|r|}
\hline \multicolumn{2}{|c|}{ Stasiun 1 (R1) } & \multicolumn{2}{c|}{ Stasiun 2 (R2) } \\
\hline $\begin{array}{r}\text { Waktu } \\
\text { (menit) }\end{array}$ & $\begin{array}{c}\text { Curah Hujan } \\
\text { (mm/jam) }\end{array}$ & $\begin{array}{c}\text { Waktu } \\
\text { (menit) }\end{array}$ & $\begin{array}{c}\text { Curah Hujan } \\
\text { (mm/jam) }\end{array}$ \\
\hline \hline 0 & 0.00 & 0 & 0.00 \\
60 & 8.00 & 60 & 8.00 \\
120 & 11.00 & 120 & 10.00 \\
180 & 12.20 & 180 & 11.00 \\
240 & 11.00 & 240 & 9.50 \\
300 & 10.00 & 300 & 9.00 \\
360 & 4.00 & 360 & 5.00 \\
420 & 1.00 & 420 & 1.00 \\
\hline
\end{tabular}

\subsubsection{Skenario 2}

Simulasi untuk skenario ini dilakukan dengan curah hujan yang terukur pada tanggal 28 Maret 1994 pada kedua pos hujan yang sama. Lihat tabel di bawah ini.

Tabel 2 Curah hujan pada dua stasiun.

\begin{tabular}{|r|r|r|r|}
\hline \multicolumn{2}{|c|}{ Stasiun 1 (R1) } & \multicolumn{2}{c|}{ Stasiun 2 (R2) } \\
\hline $\begin{array}{r}\text { Waktu } \\
\text { (menit) }\end{array}$ & $\begin{array}{c}\text { Curah Hujan } \\
\text { (mm/jam) }\end{array}$ & $\begin{array}{c}\text { Waktu } \\
\text { (menit) }\end{array}$ & $\begin{array}{c}\text { Curah Hujan } \\
\text { (mm/jam) }\end{array}$ \\
\hline \hline 60 & 6 & 60 & 8 \\
120 & 12 & 120 & 12 \\
180 & 14 & 180 & 14 \\
240 & 10 & 240 & 12 \\
300 & 9 & 300 & 10 \\
360 & 7 & 360 & 10 \\
420 & 5 & 420 & 7 \\
60 & 6 & 60 & 8 \\
\hline
\end{tabular}

\subsubsection{Skenario 3}

Pemodelan dengan skenario ini dilakukan untuk hujan tanggal 28 Pebruari 1994, seperti tabel di berikut ini. 
Pemodelan Hubungan Hujan, Limpasan dan Kapasitas Erosi 67

Tabel 3 Curah hujan pada dua stasiun.

\begin{tabular}{|r|c|r|c|}
\hline \multicolumn{2}{|c|}{ Stasiun R1 } & \multicolumn{2}{c|}{ Stasiun R2 } \\
\hline $\begin{array}{c}\text { waktu } \\
\text { (menit) }\end{array}$ & $\begin{array}{c}\text { Curah Hujan } \\
\text { (mm/jam) }\end{array}$ & $\begin{array}{c}\text { waktu } \\
\text { (menit) }\end{array}$ & $\begin{array}{c}\text { Curah Hujan } \\
\text { (mm/jam) }\end{array}$ \\
\hline \hline 0 & 0 & 0 & 0 \\
60 & 8 & 60 & 7 \\
120 & 11 & 120 & 9.5 \\
180 & 12 & 180 & 10 \\
240 & 11 & 240 & 9.5 \\
300 & 10 & 300 & 9 \\
360 & 8 & 360 & 7 \\
420 & 4 & 420 & 5 \\
6000 & 0 & 6000 & 0 \\
\hline
\end{tabular}

\subsection{Output spasial dari simulasi model}

\subsubsection{Skenario 1}

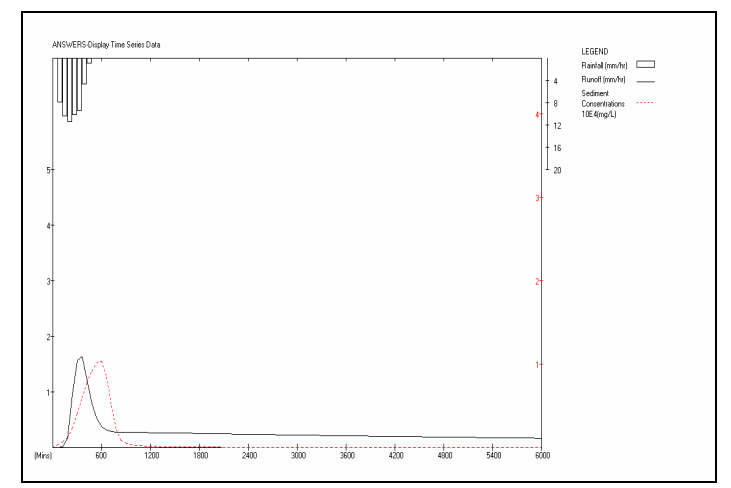

Gambar 9 Grafik hidrograf dan konsentrasi sedimen akibat hujan.

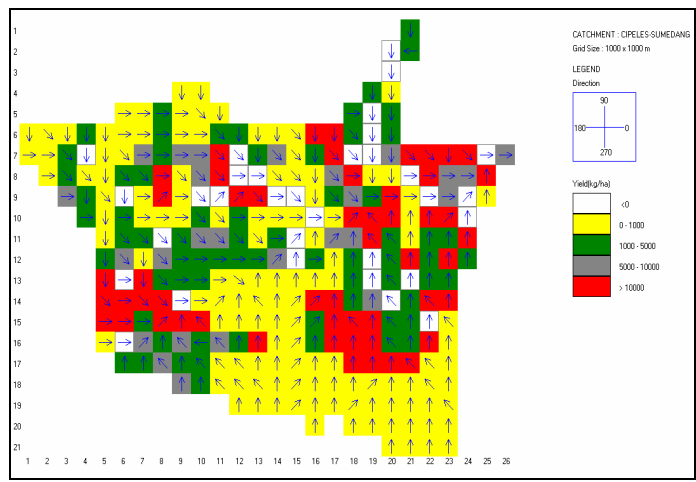

Gambar 10 Spasial Sedimen dari Skenario 1. 


\subsubsection{Skenario 2}

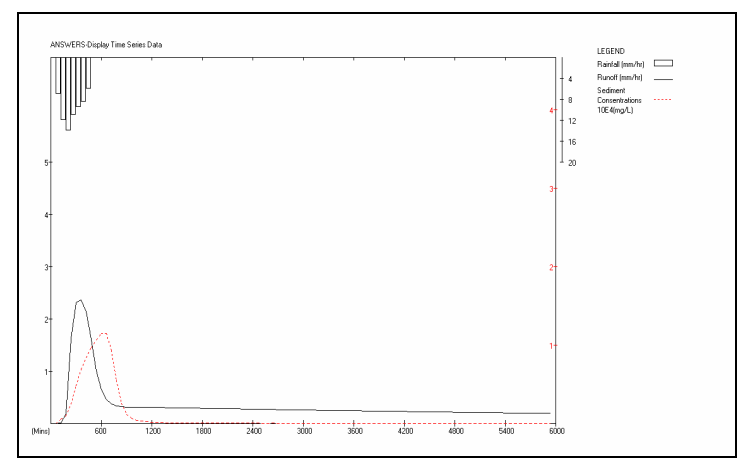

Gambar 11 Grafik hidrograf dan konsentrasi sedimen akibat hujan.

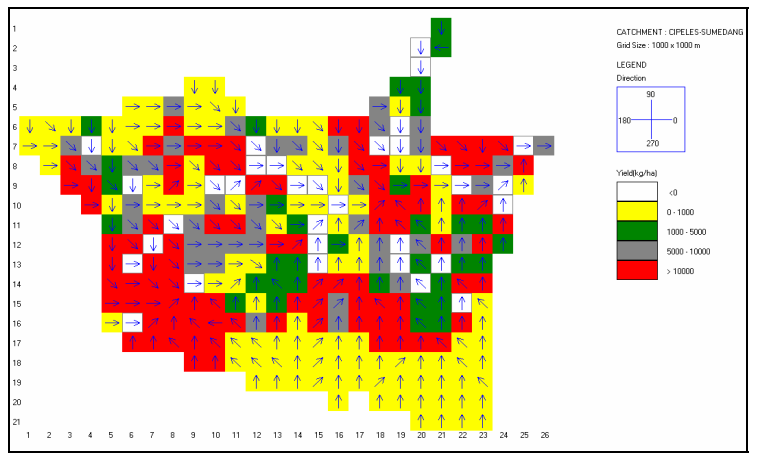

Gambar 12 Spasial Sedimen dari Skenario 2.

\subsubsection{Skenario 3}

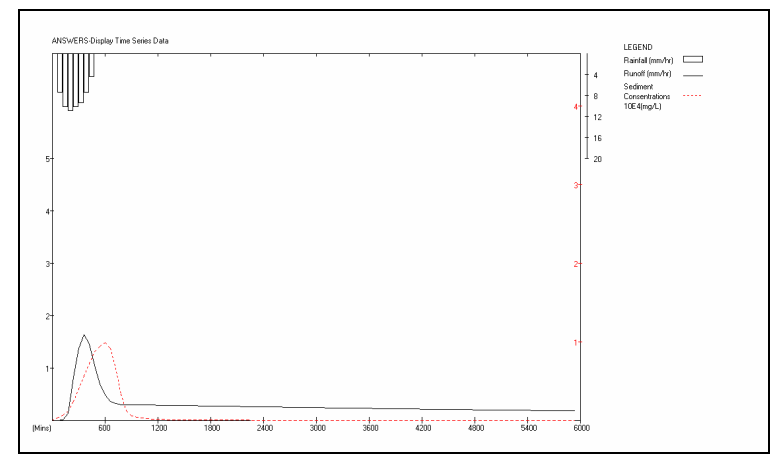

Gambar 13 Grafik hidrograf dan konsentrasi sedimen akibat hujan. 


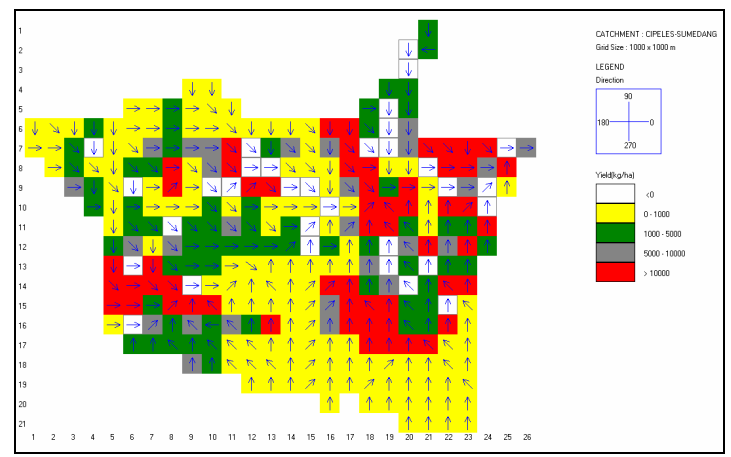

Gambar 14 Spasial Sedimen dari Skenario 3.

\section{Diskusi}

Verifikasi memberikan nilai penyimpangan $6,30 \%$ dan angka korelasi $\left(\mathrm{R}^{2}\right)$ sebesar 0,92. Dari hasil ini pada prinsipnya masih dapat ditingkatkan lagi apabila ketersediaan data karakteristik DAS seperti penutup dan tata guna lahan cukup akurat, disamping itu tentu representatif hujan pada wilayah tinjaun sangat diperlukan. Mengacu pada hasil verifikasi model ANSWERS pada kasus Sub DAS Cipeles tersebut menunjukkan bahwa pemodelan pada DAS sangat banyak parameter yang berpengaruh. Hal ini dikarenakan karakteristik DAS lebih kompleks dibandingkan dengan saluran alam atau sungai. Pemodelan pada DAS, salah satu variabel yang amat berpengaruh adalah tata guna lahan. Kalau terjadi perubahan tata guna lahan cukup signifikan merubah pola limpasan dan erosi yang terjadi. Kondisi ini dapat dilihat pada beberapa kasus riil di Indonesia, dimana pada daerah yang terjadi perubahan lahan dapat menyebabkan perubahan lingkungan secara drastis, terutama erosi lahan.

Dari hasil simulasi dengan tiga skenario berdasarkan variasi curah hujan (gambar $9 \mathrm{~s} / \mathrm{d}$ gambar 14) tersebut di atas menunjukkan bahwa pola hujan cukup signifikan mempengaruhi kapasitas erosi yang terjadi. Hal ini dapat dilihat perbedaan antara gambar 10,12 dan gambar 14 (nilai paling kecil warna putih dan paling besar warna merah). Dalam pacu model skenario 1 (gambar 10), erosi yang terjadi kebanyakan dengan kapasitas $1000-5000 \mathrm{~kg} / \mathrm{ha}$ (kuning ke hijau), sedangkan hasil simulasi dengan skenario 2 (gambar 12), erosi yang terjadi cenderung antara kuning, hujau dan merah (1000-10000 kg/ha). Sedangkan skenario 3 (gambar 14) hampir sama dengan hasil skenario 1 yaitu eorsinya berkisar $1000-5000 \mathrm{~kg} / \mathrm{ha}$. Hal ini dikarenakan pola hujan antara skenario 1 dan 2 mempunyai tren dan magnitud yang hampir sama.

Dari hasil pemodelan pada Sub DAS Cipeles, ada beberapa informasi yang diperoleh terutama dalam pengelolaan suatu DAS. Dengan menggunakan model 
ini sedikitnya dapat memprediksi besarnya erosi suatu lahan dengan pola hujan dan tata guna tertentu. Erosi ini perlu diketahui karena pengaruh ke hilir sungai sangat besar. Kalau kita lihat kondisi sungai citanduy yang banyak membawa sedimen layang, seandainya dalam penelitian tahun pertama ini sudah memiliki data DAS Citanduy yang lengkap, maka akan dapat dimodelkan untuk memperoleh informasi seberapa besar kontribusi erosi DAS yang masuk ke sungai Citanduy. Kalau informasi ini bisa diperoleh, maka penanganan dan pengelolaan sungai Citanduy pada bagian hilir, salah satu pendekatannya dapat dilakukan penanganan dihulu sungai seperti konservasi lahan dan lain-lain.

\section{Kesimpulan dan Saran}

\subsection{Kesimpulan}

Akurasi dari verifikasi model ANSWERS terhadap kasus lapangan sangat ditentukan oleh reperesentasi curah hujan yang berlaku pada lokasi studi, kelengkapan dari data DAS seperti tata guna lahan, jenis penutup lahan, jaringan sungai dan data tanah (termasuk yang berhubungan dengan infiltrasi). Selanjutnya dari hasil simulasi model (variasi curah hujan) memberikan informasi bahwa erosi lahan yang terjadi akan berbeda bila tren dan magnitud hujan cukup signifikan perbedaannya. Oleh sebab itu analisis terhadap hujan yang akan digunakan sebagai input model perlu dilakukan secara konprehensif dengan memperhitungkan faktor hujan wilayah.

Dari hasil pemodelan pada Sub DAS Cipeles, banyak informasi yang diperoleh terutama dalam pengelolaan suatu DAS. Dengan menggunakan model ini sedikitnya dapat memprediksi besarnya erosi suatu lahan dengan pola hujan dan tata guna tertentu. Erosi ini perlu diketahui karena pengaruh ke hilir sungai sangat besar. Kondisi ini dapat dilihat pada kasus sungai citanduy yang banyak membawa sedimen layang sehingga laguna Segara Anakan cenderung terjadinya pengendapan. Untuk itu dalam kasus seperti itu, apabila dapat dimodel pola erosi lahan yang terjadi di bagian atas, maka penanganan dan pengelolaan sungai pada bagian hilir, salah satu pendekatannya dapat dilakukan penanganan di hulu sungai seperti konservasi lahan dan lain-lain.

\subsection{Saran}

Dalam melakukan pemodelan pada suatu DAS, kelengkapan data spasial sangat berpengaruh terhadap akurasi hasil model yang diperoleh. Kondisi ini sangat berbeda bila dibandingkan dengan dengan pemodelan pada sungai. Pemodelan pada sungai, ada parameter yang relatif mudah untuk estimasi dibandingkan parameter pada pemodelan DAS. Oleh sebab itu sangat dianjurkan dalam mengkaji suatu DAS, konsep karakteristik DAS tersebut sangat perlu dilakukan pada awal pemodelan. 
Namun demikian dalam melakukan pemodelan sungai, keberadaan data sebagai bahan kalibrasi memegang peranan yang penting. Dalam banyak kasus, data sebagai bahan kalibrasi relatif sulit didapatkan. Data berupa time series dalam jangka waktu yang panjang cukup sulit didapatkan. Sebagai bagian dari usaha untuk mendapatkan hasil yang pemodelan yang lebih baik, mendekati kondisi aktual di lapangan, dan berguna baik dari sisi ilmu pengetahuan maupun keinsinyuran maka pengukuran data perlu dilakukan secara berkala oleh instansi terkait.

\section{Daftar Pustaka}

1. Arsyad, S., Konservasi Tanah dan Air, IPB Press, Bogor (1989).

2. Balai rehabilitasi Lahan dan Konservasi Tanah Cimanuk-Citanduy, Buku I (Buku Utama RTL-RLKI Cipeles-Cimamik), BRLKT Bandung (2000).

3. Balai rehabilitasi Lahan dan Konservasi Tanah Cimanuk-Citanduy, Buku II (Metode Teknik dan Lampiran Data RTL-RLKT' Cipeles-Cimanuk), BRLKT Bandung (2000).

4. Beasley, D. B. \& Huggins, L. F., ANSWERS: User's Manual, US EPA. Region V. Chicago, USA (1983).

5. Bouraoui, F. \& Dillaha, T., ANSWER1-2000: Runoff and Sediment Transport Model, Journal of Environmental Engineering.

6. Chow, V. T., Handbook of Applied Hydrology, McGraw Hill Book. Company Inc., New York (1964).

7. DGWRD, Cisadane-Cimanuk Integrated Water Resources Development (BTA-155), Puslitbang Pengairan \& Delft Hydraulics.Bandung (1988).

8. Final Report, Eksploitasi Bangunan Pengemulalian Erosi Di Daerah Aliran Sungai Cimanuk, Puslitbang Air, Bandung (1983).

9. Final Report, Survey Hidrologi Monitoring Pengelolaan DAS, Direktorat sungai dengan Direktorat penyelidikan masalah air, Puslitbang Air, Bandung (1984).

10. Final Report, Penelitian Daerah Aliran Sungai Dikaitkan Dengan Kelestarian Lingkungan Hidrologi dan Pengendaliannya Alas Erosi dan Efek-efeknya, Puslitbang Air, Bandung (1992).

11. Haan, C. T., Jhonson, H. P., \& Brakensiek, D. L. (eds), Hydrologic Modelling of Small Watershed, ASAE, St. Joseph, Michigan.

12. Ilyas, M. Arief, Monitoring dan Evaluasi Sedimentasi dan Erosi, Pusat Penelitian dan Pengembangan Pengairan, Dirjen Pengairan, Dept. Pekeraan Umum, Bandung (1985).

13. Niu, Z., Byne, W., Applying ANSWERS-2000 to Simulate BMP effects on Sediment and Runoff from two Watershed in Three Gorges Area, Southern China.

14. Soemarto, C. D., Hidrologi Teknik, Usaha Nasional Surabaya (1987). 
15. Taufik, I., Analisis Pengaruh Perubahan Posisi Penggunaan Lahan di DAS Cipeles terhadap Hubungan Hujan, Debit, dan Erosi, Program Magister Teknik Sipil, Institut Teknologi Bandung (2003). 